\title{
Public Opinion, Private Remonstrance, and the Law: Protecting Animals in Australia, 1803-1914
}

\author{
Stefan Petrow
}

\section{Introduction}

Recent exposures of high rates of death aboard live animal export ships, and the 'abuse and torture' of animals in some Indonesian slaughterhouses have brought cruelty to animals to public prominence in modern Australia. ${ }^{1}$ This mistreatment offends Australians' sense of what it means to be civilised, which is reflected in the fact that every Australian state and territory has passed complex and detailed laws declaring that the ill-treatment of animals is illegal. ${ }^{2}$ These statutes affirm that 'humans have evolved to the point that they no longer regard animals as pure objects or things, able to be treated in any way they choose' ${ }^{3}$ As far as the statute law is concerned, society has expressed its 'collective choice' that anyone who subjects animals to pain, suffering or distress will be punished. ${ }^{4}$ While these statutes are a necessary protection for animals, they are not sufficient to guarantee that animals are protected. Peter Sankoff has questioned whether the animal welfare paradigm can work effectively for other than 'extreme' cases of cruelty, which represent a small fraction of all the harm humans cause animals. ${ }^{5}$ Much depends on the enforcement of the laws and, if a case makes it to court, on whether the pain or suffering is deemed reasonable and necessary. The courts rarely lay down in detail 'how the balancing test between necessity and animal harm should operate' and offenders often escape with lenient sentences. ${ }^{6}$

\footnotetext{
1 Malcolm Caulfield, 'Live Export of Animals', in Animal Law in Australasia, eds, Peter Sankoff and Steven White (Sydney: Federation Press, 2009), 153-73; Animals Australia, 'Cruel Cattle Exports to Indonesia Must Halt Immediately', press release 30 May 2011, http://www.animalsaustralia.org/media/press_releases. php?release $=151$ accessed 9 October 2011 .

2 Deborah Cao, Animal Law in Australia and New Zealand (Sydney: Law Book Co., 2010).

3 Sankoff, 'The Welfare Paradigm: Making the World a Better Place for Animals?', in Sankoff and White, 14. 4 Mike Radford, Animal Welfare Law in Britain: Regulation and Responsibility (Oxford University Press, 2001), 11.

5 Sankoff, 16

6 Sankoff, 18
} 
Mike Radford has argued that in Britain an understanding of the evolution of the legal protection of animals is 'essential for understanding the contemporary law'. ${ }^{7}$ This assessment also rings true for Australia, where the continuities are more striking than the discontinuities. Despite nearly 200 years of animal protection laws in Australia, enforcement remains 'alarmingly inadequate' and the number of cases reaching the courts is small. ${ }^{8}$ Only cases where the evidence is clear-cut are prosecuted and so most offenders plead guilty, leaving 'little case law ... to assist in future interpretation of the law'. Most of the small number of cases that are defended tend to involve factual and not legal issues. Commonly found terms in statutes such as 'unnecessary' or 'unreasonable' are applied on a case-by-case basis, depend on the interpretation of individual judges and magistrates, and give 'little idea of what actually constitutes permissible conduct'. Annabel Markham notes that, despite the trend of recent legislation to impose heavier penalties, increased severity did not result 'in any significant change in sentence levels' and 'moderate fines remain the norm'. ${ }^{9}$ Researchers studying the operation of current statutes question 'whether the protections afforded by the legislation are more symbolic than real'.

The detection of animal cruelty is difficult and typically prosecutions depend, not on the police or other government agents, but on the work of the 84 Royal Society for the Prevention of Cruelty to Animal (RSPCA) inspectors Australiawide, who investigated 53,544 complaints of cruelty and neglect involving 'farm animals, companion animals, pets and wildlife' in 2009-10. ${ }^{10}$ The inspectors possess 'wide-ranging powers' and can enter and search premises, seize animals and relieve animal suffering. ${ }^{11}$ Despite such powers, the RSPCA prosecuted only 247 cases, or about 0.46 per cent, of all the complaints its inspectors investigated and, of those cases, 185, or about 75 per cent, resulted in convictions, a high success rate due to 'a very high proportion of guilty pleas' ${ }^{12}$ Despite the high success rate, courts rarely impose custodial sentences even though only serious cases are prosecuted and usually in cases involving 'extreme violence', often verging on sadism. ${ }^{13}$ Most offenders are fined 'modest' sums and thus receive 'the least severe sentencing option'. More severe non-custodial sentences such as community service or work orders are infrequently imposed. Orders prohibiting an offender from keeping an animal for a specified period or permanently, which are suitably punitive for repeat offenders, appear not to be used extensively,

\footnotetext{
7 Radford, 94.

8 Sankoff, 18-20.

9 Annabel Markham, 'Animal Cruelty Sentencing in Australia and New Zealand', in Sankoff and White, 290.

10 RSPCA web site at http://www.rspca.org.au/what-we-do/inspectorate.html and annual statistics at http://www.rspca.org.au/resources/ accessed 9 October 2011.

11 Cao, 172.

12 RSPCA, annual statistics; Cao, 174.

13 Markham, 294-96.
} 
but more research is needed to verify that observation. ${ }^{14}$ In short, inadequate sentencing practices undermine the power of statute law to protect animals and reinforce the traditional legal status of animals as "property and not living, sentient beings s $^{15}$ The history of animal protection law reveals this pattern.

Laws protecting animals were first passed in 1837 in Van Diemen's Land, gradually spread to the other colonies in the 1840s, were extended in the 1860s, early 1900s and 1920s, and were revised in the 1950s and the 1980s in all states. ${ }^{16}$ While the level of research into historical cases of cruelty remains limited, it appears that relatively few cases of animal cruelty were prosecuted before the 1870s and, if they were, the courts held almost from their establishment that 'the protection of the animal was always legally invisible next to the primary issue of animal possession' ${ }^{17}$ No one took responsibility for prosecuting animal cruelty cases systematically until Societies for the Prevention of Cruelty to Animals (SPCA) were formed in Victoria, New South Wales and Tasmania in the 1870s. But as is the case with contemporary Australia, the percentage of complaints investigated by SPCA inspectors compared with the amount of cruelty practiced was small, the number of cases prosecuted in proportion to the cases investigated was also small, and the courts rarely imposed severe penalties on those offenders found guilty of cruelty. Circumscribed by limited resources, the SPCA also relied on educating public opinion to be kind to animals and remonstrating with individuals who mistreated animals to complement their prosecution of extreme cases of cruelty or recalcitrant owners. After 1900 the SPCA began to feel that the law was not effective in fundamentally changing human behaviour and turned more to education as their main weapon against cruelty. In this chapter, these generalisations will be supported by an examination of the operation of the law in Tasmania between 1803 and 1914, concentrating on the period from 1878 when the SPCA began its work of stamping out cruelty in Tasmania.

British developments influenced the reactions of the Australian colonies to animal cruelty and an overview of those developments follows. The law loomed large in efforts to stop brutality in Britain from the passing of the groundbreaking Cruelty to Animals Act in 1822 and the passing of many more laws thereafter expanding the definition of cruelty and making punishment more severe. ${ }^{18}$ Although there was 'educational and symbolic value in getting kindness to animals incorporated into the law', animals did not gain 'more power' or 'more freedom', and much hinged on effective law enforcement to restrict

14 Cao, 176.

15 K. Sharman, 'Sentencing Under Our Anti-Cruelty Statutes: Why Our Leniency Will Come Back to Bite Us', Current Issues in Criminal Justice 13 (2002): 334.

16 Philip Jamieson, 'Animal Welfare: A Movement in Transition', in Law and History: A Collection of Papers Presented at the 1989 Law and History Conference, ed., Suzanne Corcoran (University of Adelaide, 1989): 24.

17 B. Salter, 'Possess or Protect? Exploring the Legal Status of Animals in Australia's First Colonial Courts: Part 1, The Unnatural Theft and Murder', Australian Animal Protection Law Journal 2 (2009): 40.

18 The various statutes passed in Britain are discussed in Radford, 33-89. 
human misuse of their dominion over animals. ${ }^{19}$ The SPCA was established in 1824 (becoming the Royal SPCA in 1840) to ensure that the law was rigorously enforced, especially against the 'visible ill-treatment' of horses on urban streets; the SPCA wanted to stop cruelty from being encouraged by bad example. ${ }^{20}$ Michael Roberts is right to point out that initially the RSPCA was 'divided on the legitimacy and social effects of law enforcement as a policy' and sought to gain 'educational publicity via example-setting rather than tighter policing as an end in itself' ${ }^{21}$ After overcoming initial jealousy and suspicion, the RSPCA secured the co-operation of magistrates and the police, to support the work of its own paid inspectors and, by the 1840s, 'the principle of legislation to protect animals from cruelty had been firmly established'. ${ }^{22}$ The RSPCA was one of the few important pressure groups that 'consistently collaborated with the authorities' and this resulted in increased convictions for cruelty by $1901 .^{23}$ Most RSPCA prosecutions were of working men because their cruelty was the most visible and its officers were prevented from entering 'private places' because of 'the sacredness of alleged rights of the citizen, the domicile and of private property' ${ }^{24}$

In the second half of the nineteenth century, some animal protectionists again questioned whether using the law was the most effective way to change behaviour and warned against the dangers of infringing individual liberty by extreme legislation. ${ }^{25}$ By the 1860 s, education to reinforce prosecution had become an increasingly important part of the RSPCA's program. ${ }^{26}$ It aimed to familiarise people with the nature of animal mistreatment and to engender kindness towards animals, but also to persuade onlookers to intervene and stop cruelty. Special efforts were made by the many female members of the RSPCA to educate children in schools and through the Band of Mercy movement. ${ }^{27}$ From 1865 churches helped to educate their parishioners with sermons on Animal Sundays. ${ }^{28}$ The RSPCA skilfully mobilised 'the general public's enthusiasm and even, on occasion, its sentimentality in defence of animals' ${ }^{29}$ Despite the perseverance and courage of animal protection enthusiasts, the struggle to

19 Brian Harrison, Peaceable Kingdom: Stability and Change in Modern Britain (Oxford: Clarendon Press, 1982), 121; John Passmore, 'The Treatment of Animals', Journal of the History of Ideas 36 (1975): 212.

20 Harriet Ritvo, The Animal Estate: The English and Other Creatures in the Victorian Age (Cambridge: Harvard University Press, 1987), 138, 146; Hilda Kean, Animal Rights: Political and Social Change in Britain Since 1800 (London: Reaktion, 1998), 37, 50, 80.

21 M.J.D. Roberts, Making English Morals: Voluntary Associations and Moral Reform in England, 1787-1886 (Cambridge University Press, 2004), 135.

22 Radford, 61.

23 Harrison, 83, 93, 111, 146-50.

24 Radford, 84.

25 Kean, 35.

26 Ritvo, 147; Harrison, 129.

27 Kean, 46; Arthur W. Moss, Valiant Crusade: The History of the R.S.P.C.A. (London: Cassell, 1961), $196-98$.

28 Moss, 205-06.

29 Harrison, 108, 114, 117. 
change cultural attitudes to animals never gained full acceptance and faced ridicule and resentment, evasion and resistance, especially amongst the poor whose recreations and livelihoods they attacked. ${ }^{30}$

The 'civilizing mission' of middle-class reformers in Britain was 'exported to the colonies' and found its 'most telling expression' in the formation of animal protection societies 'devoted to notions of progress towards a higher state of civilization'. ${ }^{31}$ The key decade for the formation of animal protection societies in the Australian colonies was the 1870s, when four were formed..$^{32}$ By the 1870 s tolerance of cruelty and immoral behaviour generally had greatly lessened in the Australian colonies and the debate over vivisection in Britain renewed interest in animal protection. The next section explores the changing attitudes to cruelty in Tasmania from the 1820s to the 1870s.

\section{Changing attitudes to cruelty in Tasmania}

Settled as Australia's second colony in 1803, Tasmania began life as the island penal colony of Van Diemen's Land and gained a reputation for brutality in the treatment of convicts and the Indigenous population. ${ }^{33}$ British settlers to the island had been accustomed to be cruel to animals and 'the dominion of man' was reinforced by the freedom of all classes to hunt native animals for sport and food..$^{34}$ In 1826 the Colonial Times railed against the 'inhumanity' with which horses, oxen and other animals were treated in Van Diemen's Land. ${ }^{35}$ Each day settlers saw 'the most brutal instances of ferocity' practised on public streets by both free arrivals and convicts. The Colonial Times advocated the enactment of legislation for the prevention of cruelty to animals. In 1832 this call was supported by the editor of The Independent, who, in Launceston, daily observed 'lamentable scenes of cruelty too shocking to relate'. ${ }^{36}$

No legislation was passed and cruelty continued to attract newspaper attention. In 1834 a man was seen hitting his horse's head repeatedly with the butt of his whip and, when passers-by remonstrated with him to stop, he replied that the

\footnotetext{
30 Ritvo, 166; Kathleen Kete, 'Animals and Ideology: The Politics of Animal Protection in Europe', in Representing Animals, ed., Nigel Rothfels (Bloomington: Indiana University Press, 2002), 27.

31 Dorothee Brantz, 'The Domestication of Empire: Human-Animal Relations at the Intersection of Civilization, Evolution, and Acclimatization', in A Cultural History of Animals in an Age of Empire, ed., Kathleen Kete (Oxford: Berg, 2007), 75, 79.

32 Daily News, 22 June 1878, 3; T. Bonyhady, The Colonial Earth (Melbourne: Miegunyah Press, 2000), 154.

33 Lloyd Robson, A Short History of Tasmania, updated by Michael Roe, 2nd ed. (Melbourne: Oxford University Press, 1997).

34 David Young, Sporting Island: A History of Sport and Recreation in Tasmania (Hobart: Sport and Recreation, Tasmania, 2005), 1-4.

35 Colonial Times and Tasmanian Advertiser, 24 March 1826, 3; 17 November 1826, 3.

36 Independent (Launceston), 11 February 1832, 2.
} 
horse was his own, and he could do as he pleased with it' ${ }^{37}$ Such conduct 'can never be endured in a Christian country', where no man had 'a right to violate the laws of humanity by torturing any animal, because it is his property', declared the Colonial Times. While Lieutenant-Governor George Arthur showed no interest in dealing with animal cruelty, his successor Sir John Franklin was more temperamentally attuned to suffering of all kinds, whether human or animal. Soon after his arrival in Van Diemen's Land in 1837, Franklin travelled around the island and must have seen examples of mistreatment of animals. ${ }^{38}$ He was also presumably aware of the enactment of new British legislation in 1835 against 'cruel and improper treatment'. Whatever his motives, Franklin passed the first legislation in Australian history to prevent cruelty to animals, The Prevention of Cruelty to Animals Act, in 1837, extending to Van Diemen's Land some of the provisions of the 1835 Act, known as Pease's Act. ${ }^{39}$

Philip Jamieson calls the 1837 Act 'a pale reflection' of Pease's British Act. ${ }^{40}$ Few prosecutions were brought under the 1837 legislation possibly because, as the Chief Police Magistrate Matthew Forster suggested when the bill was debated, of 'the difficulty of determining what was cruelty' ${ }^{41}$ Moreover, the police were too preoccupied with other offences to pay much attention to animal cruelty. ${ }^{42}$ Cock-fighting and, to some extent, dog-fighting remained popular pastimes for the convict classes at least. ${ }^{43}$ In 1848 the Britannia and Trades Advocate thought that the prevention of cruelty legislation was not 'generally known' and noted 'the brutal indifference' with which men and some women treated their domestic animals. ${ }^{44}$ To show kindness and consideration to animals was held to be 'a proof of weakness, and a fair subject of ridicule'. The newspaper declared that cruelty to animals was carried out to 'a greater extent' in Van Diemen's Land than 'we have witnessed in any other part of the civilized world'. It noted the absence of lectures, sermons or instructions to teach young boys and girls 'to feel kindly' towards animals. ${ }^{45}$ The Britannia and Trades Advocate blamed women for allowing dogs to be deprived of water and food. It was 'unwomanly' to leave dogs 'pining with thirst, tied to a stake, with scarcely room to turn'. It urged teachers to educate their students to be kind to animals and the police

37 Colonial Times, 11 February 1834, 4.

38 Kathleen Fitzpatrick, Sir John Franklin in Tasmania 1837-1843 (Melbourne University Press, 1949), 117-18.

39 Franklin to Glenelg, 4 December 1837, Colonial Office 280/81, 125, Despatch 128, Australian Joint Copying Project, National Library of Australia; Jamieson, 22.

40 Jamieson, 22.

41 Hobart Town Courier, 21 July 1837, 4; for examples of prosecutions see Cornwall Chronicle, 30 January 1841, 2; Launceston Courier, 15 March 1841, 2 and Jamieson, 22.

42 Launceston Advertiser, 26 October 1844, 3; Stefan Petrow, 'After Arthur: Policing in Van Diemen's Land 1837-1846', in Policing the Lucky Country, eds, M. Enders and B. Dupont (Sydney: Federation Press, 2001), 176-98.

43 Young, 17-18, 45.

44 Britannia and Trades Advocate, 24 August 1848, 4, emphasis in original.

45 Britannia and Trades Advocate, 15 November 1849, 4. 
to enforce the 1837 Act. Individual citizens could also prosecute for cruelty, but this was even less common than police prosecutions. ${ }^{46}$ As in contemporary Australia, much animal cruelty went uninvestigated and unpunished.

Further legislation had to wait until after self-government was introduced to Tasmania in 1856. Tasmania's leading animal protectionist, the writer Louisa Anne Meredith, was 'the prime mover in having Acts passed for the protection of wildlife' ${ }^{47}$ For example, she persuaded her politician husband Charles to introduce legislation protecting black swans and this was passed in $1860 .{ }^{48}$ Other legislation was passed in the 1860s and 1870s to protect native game and birds either during the breeding season or at all times. Section 83 of the Police Act 1865 imposed a £5 fine for anyone caught 'fighting, baiting or worrying' animals, but attracted no comment in the House of Assembly. ${ }^{49}$ This was a common provision in police legislation and did not represent any particular concerns in the community. ${ }^{50}$ It appears that this legislation was rarely enforced and dogfighting, dog worrying and cockfighting were 'passively suffered' by the police, especially on Sunday afternoons, until at least $1880 .^{51}$ In June 1886 a correspondent called 'Viator' told Mercury readers that 'insensibility to animal suffering in the Australian colonies' was worse than in 'more densely populated countries of the world'. ${ }^{52}$ In Tasmania, with its experience of 'the awful cruelties of the convict era, it seems strange that cruelty to animals, tenfold more horrible and widespread, should be regarded with complacent apathy'.

Some Tasmanians found apathy increasingly intolerable and wanted to distance the colony from the cruelty and brutality of the penal past. ${ }^{53}$ Kay Daniels has characterised the three decades from 1860 to 1890 as a "period of transition in Tasmanian history from penal settlement to "civilized" society', by which she means a 'free community, increasingly dominated by the values of the middle class' ${ }^{54}$ These values included sexual purity and restraint, honesty, decency and respect for property and person. During this period, the middle class demanded an end to violence, idleness and criminality, the hallmarks of convictism, and

\footnotetext{
46 For a private prosecution that resulted in conviction see Hobarton Guardian, 7 December 1853, 3.

47 Vivienne Rae-Ellis, Louisa Anne Meredith: A Tigress in Exile (Hobart: St. David's Park Publishing, 1990), 184.

48 Louisa Anne Meredith, Tasmanian Friends and Foes, Feathered, Furred, and Finned: A Family Chronicle of Country Life, Natural History and Veritable Adventure (London: Marcus Ward, 1881), 158-59.

49 Mercury, 2 September 1865, 3.

50 Philip Jamieson, 'Duty and the Beast: The Movement in Reform of Animal Welfare Law', University of Queensland Law Journal 16 (1990-91): 241-42.

51 Mercury, 15 September 1880, 2.

52 Letter by 'Viator', Mercury, 23 June 1886, 3.

53 For a snapshot of the penal system see Robert Hughes, The Fatal Shore: A History of the Transportation of Convicts to Australia 1787-1868 (London: Pan Books, 1988), 368-424.

54 Kay Daniels, 'Prostitution in Tasmania during the Transition from Penal Settlement to "Civilized" Society', in So Much Hard Work: Women and Prostitution in Australian Society, ed., Kay Daniels (Sydney: Fontana, 1984), 23, 49.
} 
worked through many religious and benevolent institutions for the creation of a more respectable society. ${ }^{55}$ This transition was especially obvious in Hobart where, in the 1870s, middle-class Protestant moral reformers demanded that the municipal police force (established in 1858) impose order on the streets by suppressing prostitution, ruffianism and juvenile delinquency and enforcing the liquor licensing laws. ${ }^{56}$

As part of their mission to transform Hobart into a civilised society, middleclass humanitarians also demanded in the 1870s that official action be taken to stop violence against animals. Criticism was directed at the municipal police for ignoring 'scenes of brutality' that regularly occurred on Hobart streets by licensed cabmen and owners of coaches who ill-treated their horses. ${ }^{57}$ Animal protectionists thought that the modernisation of the law was urgently needed to stamp out such behaviour. They had an ally in the House of Assembly in the Fingal farmer William St Paul Gellibrand. Gellibrand's sister, Mary Selina Gellibrand, became a stalwart of the Tasmanian Society for the Protection of Cruelty to Animals (TSPCA) and no doubt urged her brother to introduce the Prevention of Cruelty to Animals Bill in October 1877, which extended 'the principles' of the British Prevention of Cruelty to Animals Act 1849 to Tasmania. ${ }^{58}$ William Gellibrand noted that similar legislation in Victoria, New Zealand and Queensland had worked 'remarkably well'. ${ }^{59}$ The bill was well received in the assembly and passed without amendment. In the Legislative Council only one member opposed the bill and it was passed with minor amendments. ${ }^{60}$

The Prevention of Cruelty to Animals Act 1877 repealed the 1837 Act. It sought to protect horses, cattle, donkeys, sheep, pigs, goats, cats, dogs and other domestic animals from being 'cruelly and unnecessarily' flogged, beaten, overdriven, overridden, overloaded, abused, tortured or otherwise ill-treated. ${ }^{61}$ Offenders who were found guilty of such offences could be fined up to $£ 10$ in a court of summary jurisdiction. But enforcement remained lax and complaints of cruelty regularly appeared in the press. ${ }^{62}$ It became clear that a SPCA was needed to give 'practical effect to the law'. ${ }^{63}$ The cause was spurred on in July 1878 by an act of 'awful barbarity' when boys in Upper Goulburn Street exposed 'a helpless

\footnotetext{
55 Peter Bolger, Hobart Town (Canberra: Australian National University Press, 1973), 135-193.

56 Stefan Petrow, 'Arabs, Boys and Larrikins: Juvenile Delinquents and their Treatment in Hobart, 18601896', Australian Journal of Legal History 2 (1996): 37-59 and 'Creating an Orderly Society: The Hobart Municipal Police 1880-1898', Labour History no. 75 (1998): 175-94.

57 Letter by 'Nec Timeo Nec Sperno', Mercury, 18 February 1875, 2.

58 Weld to Carnarvon, 21 December 1877, Despatch 59, Colonial Office 280/384, 356, National Library of Australia, Australian Joint Copying Project.

59 Mercury, 31 October $1877,3$.

60 Mercury, 7 November 1877, 2; 9 November 1877, 3.

61 Mercury, 17 May 1878, 3.

62 Letter by 'Englishman', 24 May 1878, 3; Letter by 'Justice', Mercury, 3 June 1878, 3, 3.

63 Letter by 'Justice', Mercury, 3 June 1878, 3; Mercury, 15 July 1878, 2; Third Annual Report of the TSPCA (Hobart: TSPCA, 1881), 8.
} 
cat to the worrying of dogs', and then slowly 'roasted the mutilated, suffering creature to death'. ${ }^{64}$ Public pressure forced the police to prosecute one of the boys, Michael Maguire, for throwing the cat on the fire and he was fined $£ 5$. Cruelty would continue, asserted the Mercury, unless citizens joined together in 'a corporate body for the inculcation of the principles of humanity and the strongest punishment of all forms of barbarity'. This case was the motivation for 'a small band' of animal lovers to form a local SPCA, which became the most prominent and influential pressure group in late-nineteenth-century Tasmania and led the 'crusade against the vice and brutality of the oppression of animal life' ${ }^{65}$

On 19 July 1878 a crowded public meeting, chaired by Governor Frederick Weld, formed the TSPCA. ${ }^{66}$ Royal endorsement by Queen Victoria had strengthened support for the British SPCA and Weld's presence as the Queen's representative gave the local cause 'social standing and legitimacy' ${ }^{67}$ The leading speakers highlighted man's duty to 'brute creation'. Sir James Wilson, member for Hobart in the Legislative Council, thought that they should put down cruelty with 'the strong arm of the law as an example to all ... evil doers'. The religious motivation behind the TSPCA's formation was illustrated by Dean H.B. Bromby, who stressed that prevention of cruelty was 'holy work' and constituted 'one of the foundations of Christianity'. Teaching the young to be kind to animals had social benefits: they would in later years 'possess many of the elements of nobility and betray a more considerate tenderness, more moral courage and a more chivalrous bearing towards others' ${ }^{68}$ The premier, W.R. Giblin, thought that the TSPCA was evidence of 'the growth of a vigorous and healthy sentiment in the colony' ${ }^{69}$ Cruelty stemmed from 'the assertion of a sense of dominion over the brute creation', but Giblin thought that few humans were 'fit to be entrusted with the absolute dominion of any living thing' and the TSPCA would check 'the abuse of this possession of powers to ill-treat'.

The new society had two main aims. The prime objective was to excite and sustain 'an intelligent public opinion regarding man's duty to animals'. ${ }^{70}$ The other major aim was 'to prevent cruelty to animals by enforcing, where practicable, the existing laws' and to seek new legislation when 'expedient'. The TSPCA's first annual report clearly stated that 'prevention and not punishment

\footnotetext{
64 Mercury, 15 July 1878, 2; 19 July 1878, 2.

65 C.E. Walch, The Story of the Life of Charles Edward Walch, with a Selection of His Writings (Hobart: J. Walch and Sons, 1908), lxxii; Mercury, 2 August 1887, 3.

66 Mercury, 20 July 1878, 2.

67 Radford, 47.

68 Bromby's speech was printed in full from the reporter's notes, see Mercury, 30 July 1878, 3 and drew criticism for being 'a combination of fallacies' (Letter by J.L. Livingston, see Mercury, 2 August 1878, 3).

69 Mercury, 20 July 1878, 2.

70 ibid.
} 
was the end to be attained' ${ }^{71}$ If remonstrance by 'word or by letter' did not work and the law was persistently broken, then the perpetrator was prosecuted. But the TSPCA strongly believed that, 'To educate to right thinking and right acting is a method more potent for good than to punish for wrong-doing'. After one year's work and 30 prosecutions, of which 25 resulted in convictions, the TSPCA thought it had demonstrated the need for active supervision of animals and that its aims were not 'Quixotic, wasting its resources and energies upon the impracticable'. ${ }^{72}$ The TSPCA described its work as 'coercive persuasion' ${ }^{73}$ No prosecution was undertaken without seeking the opinion of leading lawyer John Mitchell, who was the society's honorary legal adviser. ${ }^{74}$ In subsequent annual reports, the TSPCA continued to remind fellow colonists of its guiding principles that 'kindness of rebuke and remonstrance' was appropriate for offenders who were 'young and thoughtless, or poor and struggling', but warned that 'strict justice' would be applied to 'the wilfully cruel and cowardly' ${ }^{75}$

Inspired by Meredith's move to that city, a branch of the SPCA was founded in Launceston in August 1879. ${ }^{76}$ One of the founders, Anglican archdeacon Francis Hales, declared that they had not formed 'a prosecuting society' but 'an educating society'. ${ }^{77}$ Their aim should be to teach labourers and children that they had a 'duty' to treat animals 'kindly' from 'a sense of their responsibility to their Creator who formed them both'. Most cruelty arose from 'thoughtlessness' and, by helping people 'to understand the sufferings they thus inflict', the society 'might rank next to Christianity as a means of developing the highest moral instincts'. Betraying a dislike for the increasingly inquisitorial actions of the Hobart-based society, the Launceston Examiner hoped that the Launceston branch would seek rather 'to persuade than to coerce' and warned that the community 'will not tolerate a system of espionage that may become an engine of persecution' ${ }^{78}$ The branch should 'foster habits of gentleness and consideration among all social classes of the community and especially to encourage them amongst the young' ${ }^{79}$ The branch must not infringe 'individual liberty' when doing its legitimate work.

The Launceston branch, having absorbed the message, stressed in its first annual report that it had avoided exercising 'over much zeal at the outset' lest it antagonise the community and not gain public support. ${ }^{80}$ Indeed, its proceedings

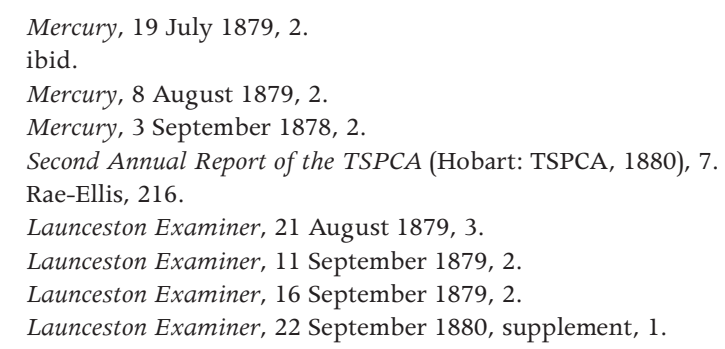


were characterised by 'such cautious discretion' that many supporters thought it was 'somewhat too conciliatory'. In most cases 'careful enquiry' was followed by 'an earnest remonstrance' to an offender and, as many cruelties arose from 'thoughtlessness, custom or gross ignorance', this was sufficient to stop cruelty. But some members thought that punishment was necessary in 'extreme or obstinate cases'. ${ }^{81}$ For example a 'thoroughly brutal' master who overloaded, flogged or starved his horse would not be 'converted to humanity by soft words only'. The branch willingly sought to punish anyone who 'persistently' disregarded 'the voice of mercy'. ${ }^{82}$ But the Launceston branch operated intermittently. In about 1885 it virtually disappeared from public view until it was reorganised in 1892, and then disappeared again around 1906 and was not reorganised until $1923 .{ }^{83}$ The lack of continuity weakened its effectiveness and the law was a dead letter when the society lapsed. The next section will examine how the SPCA went about its work in Tasmania, with special emphasis on the more active Hobart branch.

\section{Public opinion, private remonstrance and prosecution 1878-1904}

Immediately after its formation, the TSPCA set about making the Tasmanian public aware of the reason for its existence. The society realised that many people, and even the police, were unaware of the new Act and printed placards and posters outlining the society's aims and sections of the Act, which were circulated in town and country. ${ }^{84}$ The press, especially the Mercury, was a useful ally in spreading the aims of the TSPCA and denouncing cruelty to animals. ${ }^{85}$ The Mercury supported the TSPCA because it brought Tasmania 'into the fold of European humanity' ${ }^{86}$

A crucial step in building caring public attitudes towards animals was to exert influence in day and Sunday schools. ${ }^{87}$ The TSPCA believed that 'among the young - the coming men and women of our community - rests the most hopeful part of the society's operations' ${ }^{88}$ The TSPCA sought to bring into action 'the divinely implanted instincts of tenderness and love, and pity which are latent

\footnotetext{
81 Letter by ' $\mathrm{M}^{\prime}$, Launceston Examiner, 30 October 1880, 3.

82 Examiner, 9 October 1900, 7.

83 Launceston Examiner, 20 August 1892, 4; Minute book, SPCA, Launceston, 21 June 1923, NS870/1/1, Tasmanian Archives and Heritage Office (TAHO), Hobart.

84 Mercury, 24 July 1878, 3.

85 Mercury, 27 August 1878, 2.

86 Mercury, 21 October 1878, 2.

87 Mercury, 27 August 1878, 2.

88 Mercury, 19 July 1881, 3.
} 
in every child' ${ }^{89}$ Following the Victorian system, the society invited the public schools in Hobart and some schools in the country to join its Scholar's Branch and pay a fee of one penny per year per child..$^{90}$ Essay competitions were held yearly on the subject of 'man's duty to animals'. Meredith hoped that writing essays on such topics would help develop in students 'a keener perception of what is beautiful and lovable in animal nature' and that the children would note 'with gentler sympathy and sharper censure any act of cruelty they may encounter'. ${ }^{91}$ In addition to the Scholar's Branch in the schools, the TSPCA encouraged the formation of Bands of Mercy, comprised of children living in a particular district. ${ }^{92}$ The wife of the governor, Lady Teresa Hamilton called the members of bands 'soldiers, bound to stand shoulder to shoulder in the cause of mercy'.$^{93}$

By August 1887, 24 schools and Bands of Mercy had affiliated with the TSPCA and over 2000 children had become members, pledging themselves to prevent 'suffering or oppression'. ${ }^{94}$ The Board of Education agreed to tell teachers about the aims of the TSPCA. ${ }^{95}$ Sunday Schools were asked to urge 'kindness to animals upon the attention of their scholars' and four had joined by July $1882 .{ }^{96}$ Following the 'exact discipline' of the RSPCA, funds obtained from fines were not used for general running expenses or the inspector's salary, but were used to pay for literature for the Scholar's Branch. ${ }^{97}$ A legacy of $£ 100$ was devoted to pay for awards for essay prizewinners. ${ }^{98}$ Numbers for the Launceston branch are harder to divine but, by September 1880, over 700 children had enrolled in the Scholar's Branch. ${ }^{99}$ Complementing the work of the Launceston SPCA was the branch of the English Dicky Bird Society, which urged children through the columns of the Tasmanian to protect native birds and had 1680 members throughout Tasmania by $1892 .{ }^{100}$

Another crucial way in which SPCA branches spread their message was through the work of the key officer, the inspector. In Hobart, the first inspector was George Stuart, the visiting officer of the Board of Education, who was employed

\footnotetext{
89 Mercury, 2 December 1885, 3.

90 Mercury, 19 October 1878, 2; Mercury, 19 July 1879, 2.

91 Launceston Examiner, 9 June 1880, 2.

92 Mercury, 2 December 1885, 3.

93 Mercury, 6 October 1890, 4.

94 Mercury, 2 August 1882, supplement, 1; Mercury, 2 August 1887, 3.

95 Press reports of meetings, March 1880, NS 647/1/4, TAHO.

96 Mercury, 11 October 1879, 3; Fourth Annual Report of the TSPCA (Hobart: TSPCA, 1882), 11.

97 Mercury, 15 July 1880, 3; Letter by M.S. Gellibrand, Mercury, 2 April 1891, 3.

98 Second Annual Report of the TSPCA, 8.

99 Launceston Examiner, 22 September 1880, supplement, 1.

100 Will Mooney, 'Farmers' Foes or "Feathered Police"? Native Birds, Agriculture and the "Balance of Nature": Tasmania and Australia c. 1860 to 1920', Tasmanian Historical Research Association Papers and Proceedings 58, no. 2 (2011): 166; Tasmanian, 11 October 1890, 4.
} 
until July 1880 when retired police sergeant Patrick Duggan was appointed. ${ }^{101}$ Duggan was 'an esteemed ex-member of the force' and his appointment was expected to improve co-operation with the police. Duggan remained the society's inspector until his death in September 1895 when another ex-policeman, Robert Large, was appointed to the position. The inspectors visited various workplaces where livestock were used or housed, such as the wharves, stables, quarries, the railway station, cabstands, public pounds and sale yards. Duggan gave much attention to the municipal slaughter yards and ensured that sheep had not been deprived of food and water. ${ }^{102}$ The TSPCA also warned against 'the scalding of pigs before quite lifeless' and strove to exercise its powers 'to secure the merciful slaying of stock' ${ }^{103}$ The inspectors traversed Hobart and surrounding suburbs and districts warning citizens to treat their animals kindly. Duggan extended his supervision beyond the suburbs of Hobart to Glenorchy, Brighton and Bridgewater to the north, Bellerive and Sorell to the east, and Huonville to the south. ${ }^{104}$ To Duggan's 'unwearied industry, discretion and courtesy, the cause of humanity owes its strongest support', asserted the TSPCA annual report of 1884. ${ }^{105}$ Large was equally conscientious in his work and remained the inspector until his death in $1930 .{ }^{106}$

In Launceston, Meredith was disappointed at the lack of action by the municipal police and advocated appointing an inspector to enquire into and report on cases of cruelty. ${ }^{107}$ In November 1880 ex-soldier and policeman William Sessions was appointed and was sent to Hobart for a week to be tutored in his duties by Duggan. ${ }^{108}$ Sessions proved his worth after one year. In his supervision of the streets, wharves, railway stations and sale yards he detected cases of mistreatment and his work had 'a preventive influence'. ${ }^{109}$ When Sessions retired due to ill health in August 1883, the TSPCA chose another ex-soldier and former Corporation of Glasgow employee Alexander Kirkland to be its inspector. ${ }^{110}$ From about 1893 a series of short-term and part-time appointments filled the position of inspector with the help of some members who acted as honorary inspectors. ${ }^{111}$ Declining support left the branch without an inspector from about 1900 to 1914, but its work was carried on by developing closer

\footnotetext{
101 Mercury, 8 August 1878, 2; 15 August 1878, 2; 15 July 1880, 3; Second Annual Report of the TSPCA, 7; Mercury, 11 November 1880, 3; 14 September 1895, 4; 24 September 1895, 2.

102 Mercury, 5 February 1881, 3; 13 June 1882, 3; 2 December 1885, 3.

103 Mercury, 9 December 1884, 3.

104 Press reports of meetings, 10 August 1881, NS 647/1/4, TAHO.

105 Sixth Annual Report of the TSPCA (Hobart: TSPCA, 1884), 6.

106 Mercury, 25 November 1930, 6.

107 Launceston Examiner, 30 September 1880, 2; 3 November 1880, 3.

108 Mercury, 29 December 1880, 3.

109 Launceston Examiner, 14 December 1881, 3.

110 Launceston Examiner, 7 September 1883, 2.

111 Launceston Examiner, 22 August 1894, 7; 1 October 1895, 7; 1 October 1897, 5.
} 
relations with the police and state schools. ${ }^{112}$ The police prosecuted those who disregarded 'the voice of mercy', but they too put more effort into spreading 'a more intelligent conception of man's responsibilities' to animals.

The inspectors registered the names of anyone found guilty of cruelty and kept a record of cautions and remonstrances. ${ }^{113}$ They initially tried 'every power of private remonstrance before resorting to publicity and punishment'. ${ }^{114}$ This was shown in the way in which inspectors dealt with the treatment of horses, to which most of their efforts were directed. At first, Stuart tried to persuade individual owners to rest injured or tired horses. He advised owners not to turn the hose on horses 'heated and exhausted by fatiguing work', which damaged their health. ${ }^{115} \mathrm{He}$ advised cab owners that clipping horses in cold weather deprived them of 'the protection of their winter coats'. Some owners reprimanded their workers for mistreating horses and thanked Stuart for his information. ${ }^{116}$ In June 1879 Gellibrand reported that the society investigated every allegation of 'ill-usage' and received 'the willing co-operation of all those with whom it became their duty to remonstrate'. ${ }^{117}$ This proved that cruelty was due to 'ignorance or thoughtlessness' and not 'wilful barbarity' and that the work of the society was 'understood'. Inspectors such as Duggan could only deal with 'open, flagrant cases', and 'much cruelty, practised in private', was 'beyond his power to prevent or to bring forward for punishment'. ${ }^{118}$

In Launceston, Sessions issued cautions to owners not to work horses with swollen or sore collars and invariably found the amelioration had been promptly attended to'. ${ }^{119}$ In 1892 a senior member of the Launceston branch, Henry Button, claimed that the greater 'tenderness' with which horses were treated was due to 'a great extent' to the efforts and influence of the TSPCA. ${ }^{120}$ In 1894 the Launceston branch offered prizes at the agricultural show for horses that were judged to have been kept in the best condition. ${ }^{121}$ Prizes were offered to cab, racing, delivery and wood carthorses.

In addition to its efforts to educate the public and remonstrate with offenders, the TSPCA did prosecute extreme cases of cruelty. Between 1878 and 1890 the average annual number of prosecutions was 67, while between 1891 and June

\footnotetext{
112 Examiner, 9 October 1900, 7; Letter by J.E. Clarke, 6 October 1903, 6; Letter by J.M. Fysh, 1 September 1906, 10.

113 Mercury, 3 September 1878, 2.

114 Mercury, 10 September 1878, 2.

115 Mercury, 1 October 1878, 3.

116 Mercury, 19 October 1878, 2.

117 Mercury, 20 June 1879, 3.

118 Mercury, 11 August 1884, 2.

119 Launceston Examiner, 13 May 1881, 3.

120 ibid., 20 August 1892, 4.

121 ibid., 27 September 1894, 7.
} 
1904, when the society's public presence lessened, the annual average was $22 .{ }^{122}$ Most of those prosecutions involved cruelty to horses, which were numerous, for they were used in many different occupations and for transport for residents and tourists. ${ }^{123}$ As Hilda Kean has argued for Britain, their mistreatment was clearly visible on city streets and showed that the society's intervention was based on real evils not emotional overreaction. ${ }^{124}$ In Launceston details of prosecutions are patchy, with 51 prosecutions being positively recorded between 1882 and 1894. ${ }^{125}$ Presumably most prosecutions also involved horses, because Sessions found 'many' examples of horses in 'a poor and emaciated condition, underfed, badly housed, and hardly fit for work' ${ }^{126}$

Cab owners were a particular target of the TSPCA as many knowingly overused and neglected the horses in their care. In February 1879 the TSPCA tried to awaken them to their responsibilities by issuing copies of the Cruelty Act, the society's handbills and the Victorian Society for the Protection of Cruelty to Animals (VSPCA) pamphlet 'Claims of Animals'. ${ }^{127}$ Overloading of cabs continued, but the TSPCA felt powerless to stop it. The power to prevent overloading of public conveyances fell within the jurisdiction of the police by s. 153 of the Police Act 1865. ${ }^{128}$ In one case, two omnibus horses were worked so hard that at the end of the day they could barely 'crawl along'. ${ }^{129}$ After the society asked the Hobart City Council to stop 'this very cruel custom', the newly-appointed Superintendent of Police Frederick Pedder ordered his men to prevent overloading of omnibuses and night cars. ${ }^{130}$

Harder to deal with was the persistent working of horses that were lame or 'weakened by age and insufficient food'. ${ }^{131}$ The society regularly noted examples of feeble and thin horses on cabstands caused by 'scanty feeding and general inattention'. ${ }^{132}$ It was difficult to prove 'actual cruelty' under the Prevention of Cruelty Act because of 'technical difficulties' and it would take a long time to eradicate the mistreatment by 'isolated punishments'. Mistreatment could be stopped in a day if the mayor used his powers under ss. 136 and 137 of the Police Act and ordered monthly inspections of horses on cabstands. The TSPCA received support from the recently formed Hobart Town Cabmen's

\footnotetext{
122 These averages are drawn from the incomplete statistics found in annual reports of the TSPCA.

123 The economic importance of horses in Tasmania has been shown in K.M. Dallas, Horse Power (Hobart:

Fullers Bookshop, 1968).

124 Kean, 39-69.

125 Launceston Examiner, 20 December 1882, 3; 29 December 1883, 3; 9 May 1885, 3; 18 August 1893, 3;

22 August 1894, 7.

126 Launceston Examiner, 9 May 1885, 3.

127 Mercury, 7 February 1879, supplement, 1.

128 Press reports of meetings, January 1880, NS 647/1/4, TAHO.

129 Press reports of meetings, February 1880, NS 647/1/4, TAHO.

130 Press reports of meetings, February and March 1880, NS 647/1/4, TAHO.

131 Mercury, 8 August 1879, 2.

132 Mercury, 15 July 1880, 3; Second Annual Report of the TSPCA, 7.
} 
Protective Union, who wanted to raise their status 'socially and morally' and stop mistreatment of horses. This is an example of how the society's publicity and teachings in how best to treat animals could gradually change workingclass attitudes, but it also showed that the success of its message depended on individuals wanting to change that behaviour. Six members of the cabmen's union were appointed honorary members of the TSPCA. After the mayor W.H. Burgess visited the cab and car horses, he ordered that horses whose condition 'evidenced wilful neglect and under-feeding' should be withdrawn from service. ${ }^{133}$

Burgess's successor as mayor, James Harcourt, was also sympathetic to the society and in 1882 appointed Acting-Sergeant Franklin to accompany Duggan in regularly inspecting all horses used by licensed vehicles and relieve unfit horses from work. ${ }^{134}$ Cab drivers tried to evade this inspection in ingenious ways. They tried to conceal wounds by using acid and plugs of grease and hair. ${ }^{135}$ The acid was 'the most cruel agent' because it scorched the skin, caused great pain and left a suppurating sore even larger and more painful than the original injury. Horses with injured or broken knees, caused by poorly made roads, were still used by cab owners, who covered up the injuries using black ointment on kneecaps. ${ }^{136}$ Even when guilt was proved, magistrates inflicted 'trifling punishments' because of the poverty of offenders. ${ }^{137}$ The society believed that it was an 'error of justice' to award small fines for 'deliberate and repeated offences', weakening 'the vigour and discipline' of the law and the effect of the society's 'teaching of humanity'. With time, the society found that cautioning offenders did not work effectively because 'the wilfully cruel man' took advantage of 'mistaken leniency' to continue to work unfit animals many times until he was prosecuted. ${ }^{138}$ Light fines were 'a parody upon the laws' designed to stop cruelty and presaged the leniency shown by courts in the twenty-first century. ${ }^{139}$

Members of the TSPCA responded to needy offenders by giving some poor families sustenance from their own pockets while they rested an injured or tired horse, buying a new collar, lending others money to buy 'a fresh horse', or buying a 'wretched worn-out animal' so it could be destroyed. ${ }^{140} \mathrm{Cab}$ and cart horses felt the extremes of winter and members of the society distributed 72 rugs to keep them warm while standing still. But the society found that such kindnesses 'induced fresh infractions of the law' and Duggan had to prosecute

\footnotetext{
133 Town Clerk, to Secretary TSPCA, 27 July 1880, MCC 16/7/7, 608, TAHO; Mercury, 14 August 1880, 3.

134 Mercury, 25 October 1882, supplement, 1.

135 Mercury, 18 June 1883, 3.

136 Mercury, 24 February 1879, 2; 21 March 1879, 2; 4 April 1879, 2.

137 Seventh Annual Report of the TSPCA (Hobart: TSPCA, 1885), 6.

138 Mercury, 2 August 1887, 3.

139 Minute book of the SPCA, Launceston, 14 October 1902, NS870/1/1, TAHO.

140 Mercury, 21 October 1878, 2; Seventh Annual Report of the TSPCA, 7; Mercury, 2 December 1885, 3.
} 
again. ${ }^{141}$ Or, the kindness resulted in the increased trafficking of 'poor wornout suffering horses, cruelty thereby assuming a given money value'. Weak enforcement of the law and actions of generosity combined 'to crush down the fear of punishment, and ... to strengthen the power of lawlessness'. The nonenforcement of the Police Act against omnibuses, cabs and cars allowed horses with 'tottering' gaits and 'emaciated frames' to endanger the 'public safety' and defy 'humanity'. In 1885 two horses fell exhausted on to the streets, 'the last compulsory effort proving too much for aged frames weakened by semistarvation'. ${ }^{142}$

The City Council finally acted decisively in 1890 when Mayor John Watchorn ensured greater attention was paid to supervising cab horses and dealt with 'some abuses' that had previously been ignored. ${ }^{143}$ This greatly improved the way that cab horses were treated, but 'the poor omnibus horses' were licensed and supervised at the police office and only the police magistrate had the power to stop the overloading of passengers. Mary Gellibrand called this 'licensed cruelty' because those in authority did not enforce 'proper restrictions'.

The overworking of coach horses worsened to the extent that tourists from an unnamed 'neighbouring colony' described their condition in 1899 as 'a disgrace to Tasmania and a blot on civilisation'. ${ }^{144}$ The TSPCA investigation revealed some improvements. Horses were no longer driven with sores or 'cruelly flogged' and were mostly 'well fed and fairly tended'. ${ }^{145}$ But profit-hungry coach owners still used too few horses for too many passengers with heavy luggage and used weakened and small horses too often on long stages without adequate rest. In many cases of cruelty the offenders pleaded guilty and escaped with a small fine but, if evidence had been presented and witnesses examined, 'a much heavier penalty' might have been inflicted. ${ }^{146}$ This too parallels the tactics of modern-day offenders who seek to escape heavy punishment as discussed in the introduction.

Duggan was mostly judicious in the cases he brought to court and often gained a conviction, failing, thought the Mercury, only where an 'unscrupulous line of defence' was adopted. ${ }^{147}$ Police Magistrate Tarleton thought the Cruelty to Animals Prevention Act was 'a very proper Act', but 'such a highly penal statute' demanded that knowledge of guilt had to be clearly proved. ${ }^{148}$ Sometimes

\footnotetext{
141 Seventh Annual Report of the TSPCA, 7.

142 ibid.

143 Letter by M.S. Gellibrand, Mercury, 14 March 1890, 3.

144 Mercury, 31 March 1899, 2.

145 Letter by M.S. Gellibrand, Mercury, 11 April 1899, 3.

146 Mercury, 1 October 1904, 6.

147 Mercury, 3 January 1882, 2.

148 Mercury, 29 March 1879, 2; 30 April 1879, 2.
} 
Tarleton censured Duggan's 'somewhat exaggerated tone and style'. ${ }^{149}$ In February 1880 Tarleton dismissed two cases against James Hogan for using unfit horses in his carting business and accused Duggan of persecuting him. ${ }^{150}$

The acting chairman of the TSPCA James Macfarlane defended Duggan's 'cautious, considerate and yet energetic' methods. ${ }^{151}$ He reiterated that they used the law only against 'very flagrant cases' after an information had been sworn first, but for every prosecution at the police office, at least 20 cases of cruelty escaped punishment because of the 'difficulty of legal proof and non-willingness of witnesses'. As the 'influence of kindness' had 'never been forgotten', the committee felt 'surprise and pain' when reading Tarleton's remarks and denied abusing their power. Macfarlane pointed out that Tarleton had seen Hogan's horse 19 days after the cruelty had been first discovered and the wound had healed. As to the accusation of persecution, Macfarlane pointed out that Hogan and his employees had been previously convicted six times for cruelty before Tarleton himself, three times by the police and three times by the society.

The Mercury agreed that the evidence presented in the Hogan case did not justify Tarleton's 'hostility' and 'false aspersions' ${ }^{152}$ After all, Hogan had consistently broken the law and tricked Tarleton into questioning the 'steadfast impartiality' of the TSPCA's work. Hogan was typical of those owners who saw their horses 'simply as beasts of burden, or articles of merchandise' and asserted 'a right' to treat horses as they liked. ${ }^{153}$ Despite opposition and misrepresentation, the TSPCA did its work with 'discrimination, judgment and forbearance'. But the society's morale was dented by the difficulties of finding enough legal evidence to support their 'moral evidence' of cruelty. ${ }^{154}$ Cases of brutal flogging, kicking and mouth wrenching were especially difficult because Duggan was defeated by the 'technicality of evidence' and failed to secure 'the rights of justice', not least when seeking to punish the owners as well as the drivers of horses. Tarleton demanded proof in criminal cases that the owner knew that his horse was in an unfit condition to be worked, and that evidence was difficult to obtain. ${ }^{155}$ Typically in cruelty cases it was not, and is not today, always easy to determine whether suffering was 'unreasonable or unnecessary' and much depended on the circumstances of a particular case. ${ }^{156}$

\footnotetext{
149 Mercury, 15 September 1880, 3.

150 Mercury, 24 February 1882, 2; 6 March 1882, 2.

151 Letter by James Macfarlane, Mercury, 25 March 1882, 3.

152 Mercury, 28 February 1882, 2; 27 March 1882, 2.

153 Mercury, 14 November 1882, 2.

154 Seventh Annual Report of the TSPCA, 8.

155 Mercury, 1 April 1891, 2.

156 Sankoff, 14, 20.
} 
After Tarleton retired to official acclaim in 1894, his successor as police magistrate, Bernard Shaw, continued his policy. ${ }^{157}$ Shaw exercised his power feebly and Mary Gellibrand alleged that his 'sympathy actively works for the offenders' ${ }^{158}$ Statistics drawn from the annual reports of other colonial societies received by the TSPCA supported her case. In 1895-96 the average penalty imposed in Hobart was $6 \mathrm{~s} 1 / 2 \mathrm{~d}$, whereas in Victoria it was $£ 2$ and in Otago $£ 2$ 6d. ${ }^{159}$ One specific example occurred in September 1896 when the society prosecuted the notoriously brutal municipal dog-catcher Samuel Dunbabin for ill-treating a spaniel by tightening a wire noose around the dog's neck so hard that 'its eyes and tongue protruded' ${ }^{160}$ Shaw agreed that the action caused the spaniel 'unnecessary pain', but it was not an 'aggravated case' and he fined Dunbabin a mere $5 \mathrm{~s}$ and $12 \mathrm{~s}$ costs. But the example of West Coast magistrates belied any idea that the law was weak. They 'constantly imposed heavy fines for all cruel offences' and greatly reduced 'that brutality which disgraced earlier days' and taught offenders 'understanding and respect for the law'. ${ }^{161}$ Their 'courage and justice' were 'an object-lesson on the improvement which follows the firm administration' of the law. ${ }^{162}$

The brief of the TSPCA included amending the law when required and this occurred in the carrying of poultry. In October 1878 the society learnt that the legs of poultry carried to market were tied so tightly that, when they tried to struggle free, their legs fractured. ${ }^{163}$ The committee persuaded the attorneygeneral to introduce an amendment to the Police Act Amendment Act, based on Victorian legislation, to require the carrying of poultry in crates and baskets and making tying legs together an offence. ${ }^{164}$ The House of Assembly ridiculed the idea and the amendment was lost. The colonial treasurer W.R. Giblin described the suggestion as 'over-legislation', which would create 'hardship' for the poor who could not afford crates and baskets. In May 1879 Charles Meredith for the TSPCA guided through the assembly an amendment to the Cruelty to Animals Act to punish persons who caused an animal to suffer when conveying it in vehicles. ${ }^{165}$ According to British law, this included the carrying of poultry. ${ }^{166}$ By

\footnotetext{
157 Mercury, 22 September 1894, supplement, 1; Letter by 'Humanitas', Mercury, 29 September $1894,3$.

158 Letter by M.S. Gellibrand, Mercury, 12 January 1897, 4.

159 Letter by M.S. Gellibrand, Mercury, 27 November 1896, 3.

160 Mercury, 10 September 1896, 2.

161 Letter by M.S. Gellibrand, Mercury, 2 September 1902, 2.

162 Minute book of the SPCA, Launceston, 14 October 1902, NS870/1/1, TAHO.

163 Mercury, 4 October 1878, 2.

164 Mercury, 16 October 1878, 3.

165 Mercury, 23 May 1879, 3.

166 Mercury, 19 July 1879, 2.
} 
1881, Duggan reported that the amendment had been 'effectual' ${ }^{167} \mathrm{He}$ waged 'a constant warfare' against the 'improper' carrying of poultry and also dealt quickly with overcrowding in boxes and baskets. ${ }^{168}$

Another amendment to the law was introduced independently of the TSPCA. In November 1887 Dr Arthur Young, Member for East Devon, urged the House of Assembly to stop the 'cruel way' in which sheep were imported from Melbourne to Tasmania. ${ }^{169}$ They were 'driven long distances' to Melbourne and then 'closely packed' in a ship without food or water. When they arrived at Torquay in Young's electorate, they were dipped and once again packed tightly in a train at Latrobe before being sent to different areas of Tasmania. With the support of the assembly, the minister for lands, Edward Braddon, quickly introduced the Cruelty to Animals Amendment bill to ensure that sheep were not mistreated on Tasmanian trains and it passed both houses without dissent. ${ }^{170}$ The TSPCA praised the measure and hoped that, 'as occasion may show the necessity and virtue of interference, the Executive will promptly take its stand against every form of cruelty'. ${ }^{171}$

In November 1890 the society became agitated when it heard that 700 sheep had been stowed in the holds of the steamer Wendouree on top of a coal cargo and not been fed for seven days because it would 'injure the coal' ${ }^{172}$ The society failed to prosecute the captain and chief officer because the law officers of the Crown asserted that the offence had occurred on 'the High Sea' and the 1887 legislation did not apply there. The TSPCA tried hard to enforce the law so that animals carried in ships were 'properly treated' but, by 1901, had 'not succeeded to any great extent' ${ }^{\prime}{ }^{173}$ From 1891 lack of funds meant the work of the TSPCA devolved to the inspectors and Mary Gellibrand until her death in 1903, but the revival of its public activity in 1904 was accompanied by the enactment of more vigorous legislation. ${ }^{174}$

\section{The Prevention of Cruelty to Animals Act 1904 and its aftermath}

Cruelty to animals legislation had been strengthened in Britain and other Australian jurisdictions by the early twentieth century and Tasmania lagged

167 Mercury, 6 July 1881, 3.

168 Sixth Annual Report of the TSPCA, 6; Mercury, 7 December 1888, 3.

169 Mercury, 4 November 1887, 3.

170 Mercury, 8 December 1887, 4; 16 December 1887, 3.

171 Mercury, 7 December 1888, 3.

172 TSPCA committee meeting, 27 November 1890, NS647/1/1, TAHO.

173 Mercury, 16 October 1901, 2, the view of J.W. Evans.

174 Examiner, 14 December 1903, 6. 
behind. ${ }^{175}$ In October 1904 member of parliament for Cumberland, lawyer and farmer John Dennistoun Wood, arguing that every animal was 'susceptible of enduring great pain', consulted the TSPCA before introducing a new bill based on British legislation and similar to a recent Queensland statute. It extended the law's protection from domestic animals to any animal or bird, whether free or in confinement. ${ }^{176}$ Wood's bill followed British law in empowering justices to impose imprisonment of one month instead of a fine for a range of offences including 'overworking' and 'causing unnecessary suffering'. Another amendment 'authorised the destruction of any animal so diseased or injured that its existence would be a cause of misery to it' ${ }^{\prime}{ }^{177}$

Despite increasing the severity and scope of cruelty to animal provisions, the new Act did not greatly change the society's focus, but did help with prosecutions for overloading and over-driving of horses. ${ }^{178}$ After Shaw's retirement in March 1904, the new police magistrate for Hobart, W.O. Wise, interpreting the law more sympathetically, showed a greater willingness to impose 'deterrent fines' for 'wilful or thoughtless' cruelty to animals. ${ }^{179}$ The clearest example occurred in February 1905 when Thomas Johnson, alias George Birchall, felled his horse with a stone, hit it repeatedly on the head and left it lying in a drain until the next day before killing the animal and removing it on the order of the Sandfly road trust. ${ }^{180}$ Wise called this 'the grossest case of cruelty that had ever come before the court'. As Johnson had not paid two previous fines for other offences, Wise sentenced him to one month's imprisonment. This was the first imprisonment for cruelty under the new Act and, much to the society's satisfaction, Wise continued to impose severer sentences than his predecessors. ${ }^{181}$ Cases that were prosecuted by the society were still dismissed on occasion, mainly because perjury was a common practice, witnesses were reluctant to attend court and 'uncertainty' remained over the definition of overdriving, overloading and starving. ${ }^{182}$ These difficulties, and the gradual transition from the horse to the motor car, resulted in a drop in the number of prosecutions: between July 1904 and 1913 the annual average was $19 .{ }^{183}$ In Launceston, the failure of witnesses to give evidence in court was attributed by the society to a lack of 'moral courage' or a 'fear of giving offence, either for business or other reasons' ${ }^{184}$

175 Jamieson, 'Animal Welfare', 23-28.

176 Mercury, 1 October 1904, 6; 22 October 1904, 6.

177 Mercury, 17 October 1904, 7.

178 Minutes of TSPCA, 3 February 1905, NS 647/1/1, TAHO. Native fauna and birds were regarded as outside the purview of the society before 1914.

179 Mercury, 27 August 1904, 7.

180 Mercury, 15 February 1905, 4, 6.

181 Minutes of the TSPCA, 23 June 1905, NS 647/1/1, TAHO; Tasmanian News, 16 November 1905, 2.

182 Mercury, 14 March 1906, 5.

183 These figures are compiled from statistics given in annual reports.

184 Examiner, 22 February 1906, 7. 
From 1904, until it suspended public meetings with the onset of war in 1914, the TSPCA continued its work of inspection and prosecution where cautions were disregarded. ${ }^{185}$ But, active members remained in short supply (membership was a low 137 in 1913), and much of the burden fell on Large and the new secretary, educationalist Miss Fanny Garrett, who made animal protection work the main object of her life' until her death in $1926 .{ }^{186}$ Garrett was more circumspect than Mary Gellibrand and, with her quiet guidance, the society generally remained moderate in outlook, avoiding 'the realm of public spectacle'. ${ }^{187}$ While the focus of animal protectionists was on domestic animals, visiting German anthropologist and anatomist, Hermann Klaatsch noted that native animals 'were being totally exterminated, with no understanding and with no pity, the hard-hearted and ignorant colonists shooting everything on sight' ${ }^{188}$ The protection of native animals and birds was taken up by new organisations, such as the Field Naturalists Club, the Gould League of Bird Lovers and the AntiPlumage League, which complemented the work of the TSPCA branches. ${ }^{189}$

After nearly 30 years of operations, the TSPCA came to realise that laws, though still necessary to punish vicious offenders, 'will not make men and women humane, any more than it will make them moral' ${ }^{190}$ As the Mercury put it, dependence on 'prohibitory legislation and the power of punishment' would not result in 'radical improvement' in 'the habit of mind' that perpetrated 'barbarous conduct'. This view might have been related to the difficulties of securing new legislation to stop sports that resulted in the killing of animals such as pigeon-shooting matches and rabbit and hare coursing. ${ }^{191}$ The society thus renewed its efforts to form Bands of Mercy, mostly dormant since 1890. In 1907 parents and teachers were urged to inculcate in children 'the duty of being kind and considerate to all dumb creatures', especially domestic animals. ${ }^{192}$ By 1909, 18 Bands of Mercy had been affiliated with the TSPCA. ${ }^{193}$ Many of the essays written by children for the prizes offered by the society showed 'great love for animals, close observation, and great kindliness of heart'. ${ }^{194}$ Another educational initiative was the Society's appeal to the clergy to preach on 'Man's

\footnotetext{
185 Mercury, 18 June 1919, 8.

186 Letter by H.T. Gould, Mercury, 27 March 1908, 2; Thirty-Second Annual Report of the TSPCA (Hobart:

TSPCA, 1910), 7; Thirty-Sixth Annual Report of the TSPCA (Hobart: TSPCA, 1914), 16-18.

187 Kean, 145.

188 Robert Paddle, The Last Tasmanian Tiger: The History and Extinction of the Thylacine (Cambridge University Press, 2000), 168.

189 Thirty-Fourth Annual Report of the TSPCA (Hobart: TSPCA, 1912), 11.

190 Mercury, 15 March 1906, 4.

191 For example, the TSPCA-sponsored Cruelty to Animals Bill, designed to stop such practices, did not pass the second reading, Mercury, 7 November 1906, 6.

192 Mercury, 13 July 1907, 7.

193 Mercury, 17 March 1909, 6.

194 Thirty-Fourth Annual Report of the TSPCA, 13.
} 
Duty to Animals' as was done regularly in England. ${ }^{195}$ Animal Sunday sermons were first given on 12 July 1908 and became an annual event in some churches, but reached only small numbers of people. ${ }^{196}$

\section{Conclusion}

After over three decades of activity, the branches of the SPCA in Tasmania offered divergent accounts of their impact. By 1910 the secretary of the Launceston SPCA, Mrs J.M. Fysh, pointed out weaknesses that limited the branch's effectiveness. Fysh noted that the branch was dominated by women and, apart from a male chairman, men did not participate in the cruelty prevention work. ${ }^{197}$ While the police usually investigated complaints of cruelty, 'indifference and apathy' were widespread in Launceston. Men preferred to spend their spare time in pleasurable activities and not 'laying a hand on sundry slavers in horseflesh' ${ }^{198}$ Fysh later reflected that 'individual selfishness, want of thought, want of proper knowledge how to treat animals, dislike to interfere with the muchabused "liberty of the subject"' and the failure of mothers to teach children 'the principles of kindness' all worked against the society's efforts. ${ }^{199}$

The TSPCA struck a more positive note. By May 1912 it had noted significant changes in public attitudes, helped greatly by its enforcement of the law and educational initiatives. It found evidence of 'greater sensitiveness of public conscience and opinion, with acceptance of the rights of animals, and of man's duty towards them' ${ }^{200}$ In Hobart, 'cases of neglect and abuse, that formerly passed unheeded', were immediately 'noted and disapproved' and the society or the police were informed. Drivers of horses 'readily invited and acted on advice for sick animals' and accepted offers of literature on the subject. Hobart had certainly not been purged of cruelty to animals, the killing of animals for sport remained 'a relic of barbarism and savagery', and the lone inspector could not respond to the constant appeals from rural areas, but we should acknowledge what had been achieved. ${ }^{201}$ The 'moral influence' of the TSPCA had helped to change long entrenched practices and contributed to the 'uplifting and ennobling' of city life. ${ }^{202}$

\footnotetext{
195 Minutes of the TSPCA, 13 July 1908, NS 647/1/1, TAHO; Mercury, 17 March 1909, 6.

196 Thirty-Second Annual Report of the TSPCA, 5.

197 Letter by J.M. Fysh, Examiner, 23 September 1910, 3.

198 Letter by G. Garet, Examiner, 28 September 1910, 3.

199 Examiner, 9 April 1919, 6.

200 Mercury, 24 May 1912, 6.

201 The quote comes from Bishop John Mercer, Mercury, 24 May 1912, 6. See also his lecture 'Have animals souls?', Mercury, 28 June 1912, 8; Thirty-Sixth Annual Report of the TSPCA, 4.

202 Thirty-Sixth Annual Report of the TSPCA, 11.
} 
Moreover, while the two SPCA branches in Tasmania took great efforts to ensure that the law was of more than symbolic protection to animals, both faced a number of obstacles that limited their effectiveness and mirrored the experience of their counterparts throughout Australia in the twenty-first century. First, they relied on their own inspectors to prosecute cases and could not rely on the police or private individuals to initiate prosecution, leaving much cruelty untouched by the law. Second, the failure of witnesses to attend court or the use of a guilty plea by offenders obviated the need for witnesses or the presentation of evidence and contributed to the imposition of lesser penalties. Third, the number of cases reaching court was small because magistrates insisted on high evidentiary standards and dismissed cases on technical grounds relating to the extent and nature of the cruelty. Finally, magistrates were generally reluctant to impose heavy fines, even on repeat offenders, especially if they were poor and relied on animals for their livelihood. In short, the continuities between past and present in the enforcement of anti-cruelty laws are remarkably strong. They demonstrate that the weak enforcement of the law and lenient decisions of today have a long lineage and the time has come to take a completely different approach to law enforcement against animal cruelty. Unless the police are empowered to treat any harm to animals as an illegal abuse of responsibility worthy of prosecution, and unless courts are directed to impose mandatory heavier sentences for such harm, including heavy fines, custodial sentences and prohibition on keeping animals for serious cases of abuse, then animals will continue to experience pain and suffering of the kind endured over 200 years of white settlement. 